\title{
Stewart's Wilt Reactions of an International Collection of Zea mays Germ Plasm Inoculated with Erwinia stewartii
}

\author{
Jerald K. Pataky, Lindsey J. du Toit, and Noah D. Freeman, Department of Crop Sciences, University of \\ Illinois, Urbana 61801
}

\begin{abstract}
Pataky, J. K., du Toit, L. J., and Freeman, N. D. 2000. Stewart's wilt reactions of an international collection of Zea mays germ plasm inoculated with Erwinia stewartii. Plant Dis. 84:901906.

Maize accessions were evaluated in 1997, 1998, and 1999 to identify additional sources of Stewart's wilt resistance and to determine if reactions differed among accessions collected from various regions of the United States and throughout the world. The distributions of Stewart's wilt reactions rated from 1 (no appreciable spread of symptoms) to 9 (dead plants) were relatively similar among groups of accessions from all regions of the world except for those from the Mid-Atlantic/Ohio River Valley region of the United States, the southern United States, and the northeastern United States. The mean and median Stewart's wilt rating for 1,991 accessions evaluated in 1997 was 4. The mean Stewart's wilt rating for 245 accessions collected from the Mid-Atlantic/Ohio River Valley region was 3.1, which was significantly lower than that for accessions from all other regions. The mean rating for accessions from the southern United States was 3.7, which also was lower than mean ratings for accessions from all other regions. Ratings from trials in 1997 and 1998 were highly correlated $(r=0.87)$ for 292 accessions and 15 sweet corn hybrid checks evaluated in both years. Of 20 accessions rated below 2 in 1997 and 1998, seven were from Virginia, seven were from the Ohio River Valley or central Corn Belt of the United States, four were from the northern or western Corn Belt of the United States, and two were from Spain. Ratings for these accessions ranged from 1.7 to 3.1 in 1999. Ratings ranged from 2.6 to 3.7 for $F_{1}$ hybrids of these accessions crossed with one of two susceptible sweet corn inbreds, CrseW30 or Crse16, which were rated 5.7 and 5.4, respectively. Based on the reactions of this collection of germ plasm, it appears that high levels of Stewart's wilt resistance are prevalent only among accessions collected from areas where the disease has been endemic for several years, whereas moderate levels of resistance can be found in accessions collected from nearly everywhere in the world.
\end{abstract}

Stewart's bacterial wilt of corn (Zea mays), caused by Erwinia stewartii (syn. Pantoea stewartii), is endemic in the United States from the Mid-Atlantic States through the Ohio River Valley to Missouri and Iowa (14). Epidemics of Stewart's wilt also occur sporadically $500 \mathrm{~km}$ north or south of this area, including important areas of field corn seed production in Iowa, Illinois, and Indiana. Despite the widespread occurrence of E. stewartii over an extensive area of the U.S. Corn Belt, Stewart's wilt causes relatively minor reductions in yield of field corn because most hybrids currently grown in the Midwestern United States have adequate levels of resistance. Stewart's wilt can be problematic in seed production because many countries prohibit or place restrictions on importation of maize seed produced in fields where Stewart's wilt occurs (3).

Corresponding author: J. K. Pataky

E-mail: j-pataky@uiuc.edu

Accepted for publication 1 May 2000.

Publication no. D-2000-0612-02R

(C) 2000 The American Phytopathological Society
Stewart's wilt also can cause considerable damage to sweet corn hybrids with inadequate levels of resistance, including certain hybrids grown commonly for processing and many early-maturing hybrids (11). The magnitude of yield reduction in sweet corn is associated with the growth stage at which plants are infected and the level of resistance or susceptibility of the hybrid (17). Levels of resistance adequate to prevent yield reduction are available in some sweet corn germ plasm, but resistance must be incorporated into susceptible, earlymaturing sweet corn germ plasm and into germ plasm derived from susceptible lines with superior characteristics for processing, such as the hybrid Jubilee. Simply inherited resistance to Stewart's wilt identified from a field corn inbred, Va 35, (9) is currently being incorporated into susceptible sweet corn. Resistance from late-maturing sweet corn lines (8) also has been incorporated into earlier-maturing lines (J. K. Pataky, unpublished). In addition to these efforts, other sources of resistance that are relatively simply inherited and which strictly limit the movement of $E$. stewartii in infected plants should be used to improve and diversify Stewart's wilt resistance in sweet corn.
Resistance to common diseases is found frequently among collections of plants from the center of origin or gene centers of the cultivated plant species (7). Maize may have been domesticated more than once and may have multiple sites of origin in Central America and Mexico (7). However, it is unlikely that diverse sources of Stewart's wilt resistance are prevalent in germ plasm collected from the center of origin of maize or from most other regions of the world because the distribution of $E$. stewartii is restricted primarily to corngrowing areas of the United States where the insect vector, Chaetocnema pulicaria, is common (13). Stewart's wilt has been reported infrequently from Central America, Europe, and Asia. While attempting to identify additional sources of resistance to Stewart's wilt, it would be useful to determine if germ plasms collected from certain regions of the world are more resistant and should be examined more thoroughly.

The objectives of this research were to identify additional sources of Stewart's wilt resistance from 2,000 maize accessions obtained from the NCRPIS and to determine if Stewart's wilt reactions differed among accessions collected from various regions of the United States and throughout the world.

\section{MATERIALS AND METHODS}

Accessions were inoculated with $E$. stewartii and evaluated for Stewart's wilt reactions in field trials in 1997, 1998, and 1999. Sweet corn hybrids with known reactions to Stewart's wilt were included in or planted adjacent to each trial.

Trial in 1997. Two thousand maize accessions were obtained from the 14,000 accessions maintained at North Central Regional Plant Introduction Station (NCRPIS), Ames, IA. Accessions were selected by Mark Millard, NCRPIS maize curator, as representative of sweet corn and field corn germ plasm from the United States and maize germ plasm adapted for temperate climates from all other regions of the world. The 2,000 accessions were planted 22 May at the University of Illinois South Farm, Urbana. The trial included two replicates of single rows of approximately 15 plants per accession. Rows were spaced $0.76 \mathrm{~m}$ apart. Plant stands were adequate for all but 9 accessions. Of the 1,991 accessions evaluated, 938 were collected originally from the United States, and 1,053 were collected from other coun- 
Table 1. Mean Stewart's wilt ratings in 1997, standard deviations, ranges, and number of maize accessions from various regions of the world rated below 2 , from 2 to 2.99 , from 3 to 4.99 , and above 4.99

\begin{tabular}{|c|c|c|c|c|c|c|c|c|}
\hline \multirow[b]{2}{*}{$\operatorname{Region}^{x}$} & \multirow[b]{2}{*}{$n$} & \multicolumn{3}{|c|}{ Stewart's wilt ratings ${ }^{y}$} & \multicolumn{4}{|c|}{ No. of accessions } \\
\hline & & Mean & SD & Range & $<2$ & 2-2.99 & 3-4.99 & $\geq \mathbf{5}$ \\
\hline U.S. - Mid-Atlantic/Ohio River Valley & 245 & $3.1 \mathrm{a}$ & 0.92 & $1-6.3$ & 23 & 77 & 134 & 11 \\
\hline U.S. - South & 169 & $3.7 \mathrm{~b}$ & 0.94 & $1.5-8$ & 1 & 29 & 128 & 11 \\
\hline U.S. - West and Southwest & 116 & $4.0 \mathrm{c}$ & 0.99 & $1.5-6.3$ & 2 & 15 & 79 & 20 \\
\hline U.S. - northern and central Corn Belt & 315 & $4.0 \mathrm{c}$ & 1.23 & $1.3-7.5$ & 7 & 51 & 181 & 76 \\
\hline U.S. - unknown origin & 33 & $4.0 \mathrm{c}$ & 1.22 & $2-8$ & 0 & 5 & 22 & 6 \\
\hline Africa & 82 & $4.1 \mathrm{~cd}$ & 1.07 & $2-7.3$ & 0 & 7 & 55 & 20 \\
\hline South America & 207 & $4.2 \mathrm{~d}$ & 1.02 & $2.3-8.3$ & 0 & 19 & 142 & 46 \\
\hline Europe & 582 & $4.3 \mathrm{~d}$ & 0.86 & $1.5-8$ & 5 & 17 & 422 & 138 \\
\hline North and Central Americaz & 44 & $4.4 \mathrm{de}$ & 1.59 & $2-9$ & 0 & 3 & 32 & 9 \\
\hline Asia/South Pacific/Middle East & 138 & $4.4 \mathrm{de}$ & 1.04 & $2-7.8$ & 0 & 7 & 91 & 40 \\
\hline U.S. - Northeast & 60 & $4.6 \mathrm{e}$ & 1.09 & $2.5-8.5$ & 0 & 1 & 37 & 22 \\
\hline
\end{tabular}

${ }^{x}$ Region from which accessions were collected.

y Stewart's wilt ratings from 1 to 9 , where $1=$ little or no spread, $2=$ spread of about $3 \mathrm{~cm}, 3=$ spread toward tip end of leaf only, $5=$ limited systemic infection, $9=$ dead plants. Means followed by the same letter are not different based on all possible comparisons by $t$ tests.

${ }^{\mathrm{z}}$ North and Central America excluding the United States.

Table 2. Stewart's wilt reactions of sweet corn hybrids included as standards in the 1997 disease nursery planted adjacent to the evaluation of maize accessions

\begin{tabular}{lccc}
\hline & & \multicolumn{2}{c}{$\mathbf{1 9 9 7}$} \\
\cline { 4 - 4 } Hybrid & Previous reaction $^{\mathbf{x}}$ & Stewart's wilt rating $^{\mathbf{y}}$ & Hybrid reaction $^{\mathbf{z}}$ \\
\hline Florida Staysweet & MR-R & 3.8 & $\mathrm{M}$ \\
Day Star & MR-M & 2.8 & MR \\
Green Giant Code 27 & $\mathrm{R}$ & 2.2 & R-MR \\
Jubilee & $\mathrm{S}$ & 5.7 & $\mathrm{~S}$ \\
Miracle & $\mathrm{R}-\mathrm{MR}$ & 1.9 & $\mathrm{R}$ \\
Phenomenal & MS-M & 4.2 & M-MS \\
Summer Sweet 7710 & $\mathrm{R}-\mathrm{MR}$ & 2.7 & MR \\
Sweetie 82 & MR-M & 3.4 & M \\
Ultimate & $\mathrm{R}$ & 2.8 & MR \\
\hline
\end{tabular}

${ }^{\mathrm{x}}$ Reaction in previous years (1984 to 1996).

y Stewart's wilt rating from 1 to 9 , based on three replicates, where $1=$ little or no spread, $2=$ spread of about $3 \mathrm{~cm}, 3=$ spread toward tip end of leaf only, $5=$ limited systemic infection, $9=$ dead plants.

${ }^{\mathrm{z}}$ Reaction based on classification of Stewart's wilt ratings in 1997 (11).

tries. A field adjacent to this trial contained a Stewart's wilt evaluation of 275 sweet corn hybrids including 9 standards with consistent reactions to Stewart's wilt (11).

Plants at the three- to six-leaf stage were inoculated with E. stewartii on 25 and 30 June in the first and second replicates, respectively, using the pinprick method $(1,4)$. Inoculum was produced as described previously (17) from a mixture of isolates, including those collected in May 1997 from naturally infected plants in southern Illinois and those isolated from trials in Illinois in 1996 and maintained over winter in the greenhouse and at $-80^{\circ} \mathrm{C}$.

Reactions to $E$. stewartii were rated on a 1 to 9 scale (11), where $1=$ no appreciable spread of symptoms from pinpricks; $2=$ limited spread with water-soaking, chlorosis, or necrosis within $3 \mathrm{~cm}$ of pinpricks; 3 $=$ limited spread from pinpricks with water-soaking, chlorosis, or necrosis predominantly toward tips of leaves; $4=$ abundant spread from pinpricks with water-soaking, chlorosis, or necrosis toward both ends of inoculated leaves, but no symptoms on noninoculated leaves; $5=$ minimal systemic infection observed as small, linear streaks of symptoms on noninoculated leaves; $6=$ moderate systemic infection with 5 to $25 \%$ symptomatic leaf area of noninoculated leaves and minimal stunting; 7 = abundant systemic infection and stunting with 25 to $50 \%$ of the leaf area symptomatic; $8=$ severe systemic infection and stunting with 50 to $90 \%$ of the plant infected; and $9=90$ to $100 \%$ infection, severe necrosis, or dead plants. Each row was assigned a pair of Stewart's wilt ratings by two people. Rows were rated 8 to 11 July and 16 to 17 July in the first and second replicates, respectively. The mean rating for each row was the dependent variable in the ANOVA. Accession means were compared by a Waller-Duncan Bayesian LSD value $(k=100)$.

Accessions were grouped according to the region from which they were collected. Simple statistics and distributions were compared among regions. All possible combinations of means for regions were compared by $t$ tests $(P<0.05)$. Simple statistics and distributions also were compared for accessions grouped by countries or states within each region. The number of accessions with mean ratings below 2 , from 2 to 2.99 , from 3 to 4.99 , and above 5 were compared among regions.

Trials in 1998. Groups of selected accessions were evaluated in three separate but adjacent trials in Urbana, IL, in 1998. One trial included three replicates of 80 accessions with the lowest Stewart's wilt ratings from 1997 (38 accessions rated below 2 and 42 accessions rated 2) and 15 sweet corn hybrid checks. Another trial included two replicates of 52 accessions rated 2.25 in 1997, 67 accessions rated 2.5 in 1997, and 9 sweet corn hybrid checks. A third trial included a single replicate of 100 accessions selected randomly from the 1,986 accessions evaluated in 1997 and 6 sweet corn hybrid checks. Two replicates of $11 \mathrm{~F}_{1}$ hybrids from crosses of selected accessions and susceptible sweet corn inbreds, CrseW30 or Crse16, also were evaluated with the 100 accessions selected randomly in 1998.

All trials were planted on 17 May in contiguous plots at the University of Illinois South Farm. Each experimental unit was a single row of approximately 15 plants. Plants in all trials were inoculated 17, 23, and 30 June with a mixture of $E$. stewartii isolates. Reactions to Stewart's wilt were rated from 1 to 9 on 5 to 7 July prior to tassel emergence and on 15 to 16 July after tassels emerged. Each row was assigned a pair of Stewart's wilt ratings by two people. The mean rating of each row was the dependent variable in the ANOVAs. Accession means were compared by Waller-Duncan Bayesian LSD values $(k=$ 100). Correlation coefficients were calculated from accession means of pre- and post-tassel ratings in 1998 and for 1997 and 1998 accession means.

Trial in 1999. Five replicates of 20 accessions with the lowest Stewart's wilt ratings in 1997 and 1998, five sweet corn hybrid checks, $31 \mathrm{~F}_{1}$ hybrids from crosses of the 20 accessions and susceptible sweet corn inbreds, CrseW30 or Crse16, and the two susceptible sweet corn inbreds were evaluated in a trial in 1999. The trial was planted 11 May at the University of Illinois South Farm, Urbana. Each experimental unit was a single row of approximately 15 plants. Plants were inoculated 3, 10, and 17 
Table 3. Mean Stewart's wilt ratings in 1997, standard deviations, ranges, and number of accessions from various states in the United States rated below 2 , from 2 to 2.99 , from 3 to 4.99 , and above 4.99

\begin{tabular}{|c|c|c|c|c|c|c|c|c|}
\hline \multirow[b]{2}{*}{ Region and state ${ }^{y}$} & \multirow[b]{2}{*}{$n$} & \multicolumn{3}{|c|}{ Stewart's wilt ratings ${ }^{\mathrm{z}}$} & \multicolumn{4}{|c|}{ No. of accessions } \\
\hline & & Mean & SD & Range & $<2$ & 2-2.99 & 3-4.99 & $\geq \mathbf{5}$ \\
\hline \multicolumn{9}{|l|}{ Mid-Atlantic/Ohio River Valley } \\
\hline Virginia & 46 & 2.5 & 0.76 & $1-3.8$ & 12 & 18 & 16 & 0 \\
\hline Kentucky & 10 & 2.6 & 0.58 & $1.8-3.5$ & 2 & 4 & 4 & 0 \\
\hline Tennessee & 20 & 3.0 & 0.68 & $1.5-4$ & 1 & 7 & 12 & 0 \\
\hline Pennsylvania & 42 & 3.0 & 0.70 & $1.3-5$ & 1 & 14 & 26 & 1 \\
\hline Missouri & 29 & 3.1 & 0.81 & $1.5-4.8$ & 4 & 4 & 21 & 0 \\
\hline Ohio & 16 & 3.1 & 1.02 & $2-5.8$ & 0 & 9 & 5 & 2 \\
\hline Illinois & 44 & 3.3 & 1.05 & $1.5-5$ & 3 & 13 & 24 & 4 \\
\hline West Virginia/Maryland/New Jersey & 8 & 3.5 & 1.48 & $2.5-6.3$ & 0 & 3 & 4 & 1 \\
\hline Indiana & 30 & 3.7 & 0.85 & $2.3-5.3$ & 0 & 5 & 22 & 3 \\
\hline \multicolumn{9}{|l|}{ South } \\
\hline Mississippi & 11 & 3.1 & 0.36 & $2.3-3.8$ & 0 & 1 & 10 & 0 \\
\hline North Carolina & 23 & 3.5 & 1.06 & $2-6.3$ & 0 & 6 & 15 & 2 \\
\hline Arkansas & 6 & 3.7 & 1.28 & $2-5.5$ & 0 & 2 & 3 & 1 \\
\hline Georgia & 38 & 3.7 & 0.86 & $2-6.5$ & 0 & 5 & 30 & 3 \\
\hline South Carolina & 72 & 3.7 & 0.75 & $1.5-5$ & 1 & 10 & 59 & 2 \\
\hline Florida & 12 & 3.8 & 1.80 & $2.5-8$ & 0 & 4 & 6 & 2 \\
\hline Alabama/Louisiana & 7 & 3.9 & 1.22 & $2.8-6$ & 0 & 1 & 5 & 1 \\
\hline \multicolumn{9}{|l|}{ West and Southwest } \\
\hline Kansas & 14 & 3.2 & 0.53 & $2.5-4.5$ & 0 & 3 & 11 & 0 \\
\hline Texas & 16 & 3.2 & 0.78 & $1.8-4.5$ & 1 & 4 & 11 & 0 \\
\hline Colorado & 22 & 3.6 & 0.69 & $2.3-4.8$ & 0 & 4 & 18 & 0 \\
\hline California/Idaho & 10 & 4.0 & 0.78 & $2.8-5$ & 0 & 1 & 8 & 1 \\
\hline Oklahoma & 12 & 4.1 & 1.05 & $2.5-6$ & 0 & 2 & 8 & 2 \\
\hline Arizona & 24 & 4.3 & 0.92 & $1.5-5.5$ & 1 & 1 & 15 & 7 \\
\hline New Mexico & 11 & 4.9 & 0.80 & $3.5-6$ & 0 & 0 & 5 & 6 \\
\hline Wyoming & 7 & 5.2 & 0.81 & $4.3-6.3$ & 0 & 0 & 3 & 4 \\
\hline \multicolumn{9}{|l|}{ Northern and central Corn Belt } \\
\hline Michigan & 13 & 3.2 & 0.43 & $2.5-3.8$ & 0 & 3 & 10 & 0 \\
\hline Iowa & 127 & 3.7 & 1.14 & $1.3-7.5$ & 3 & 28 & 76 & 20 \\
\hline Nebraska & 23 & 3.7 & 1.01 & $1.5-5.5$ & 1 & 2 & 16 & 4 \\
\hline Wisconsin & 32 & 3.9 & 1.41 & $1.5-7$ & 2 & 9 & 12 & 9 \\
\hline Minnesota & 42 & 4.4 & 1.02 & $2-7$ & 0 & 3 & 23 & 16 \\
\hline North Dakota & 57 & 4.4 & 1.30 & $2-7.5$ & 0 & 4 & 35 & 18 \\
\hline South Dakota & 21 & 4.5 & 1.47 & $1.3-6.5$ & 1 & 2 & 9 & 9 \\
\hline \multicolumn{9}{|l|}{ Northeast } \\
\hline Connecticut & 16 & 4.3 & 0.55 & $3.3-5.3$ & 0 & 0 & 15 & 1 \\
\hline New York & 22 & 4.3 & 1.02 & $2.5-6.5$ & 0 & 1 & 14 & 7 \\
\hline Massachusetts & 12 & 5.2 & 1.07 & $3.8-7.8$ & 0 & 0 & 5 & 7 \\
\hline Rhode Island/Maine & 10 & 5.4 & 1.46 & $3-8.5$ & 0 & 0 & 3 & 7 \\
\hline \multicolumn{9}{|l|}{ United States } \\
\hline Unknown origin & 33 & 4.0 & 1.22 & $2-8$ & 0 & 5 & 22 & 6 \\
\hline
\end{tabular}

y Region and state from which accessions were collected.

z Stewart's wilt ratings from 1 to 9 , where: $1=$ little or no spread, $2=$ spread of about $3 \mathrm{~cm}, 3=$ spread toward tip end of leaf only, $5=$ limited systemic infection, $9=$ dead plants.

June with a mixture of $E$. stewartii isolates. Reactions to Stewart's wilt were rated from 1 to 9 at about the six-leaf stage on 22 June and on 21 July after tassels emerged. Each row was assigned a pair of Stewart's wilt ratings. The mean rating of each row was the dependent variable in the ANOVA. Means were compared by Waller-Duncan Bayesian LSD values $(k=$ $100)$. Correlation coefficients were calculated for pre- and post-tassel ratings in 1999 and for 1997, 1998, and 1999 means.

\section{RESULTS}

Trial in 1997. Reactions to Stewart's wilt differed considerably among the 1,986 accessions (Table 1). Accession mean ratings ranged from 1 to 9 with a trial mean and median of 4 and a standard deviation of 1.1. The mean separation value (BLSD) for comparison of ratings between accessions was 1.56. A list of accession means is available upon request from the corre- sponding author. Stewart's wilt reactions of sweet corn hybrids in the field adjacent to the accessions ranged from 1.6 to 6 (11), and reactions of standard hybrids were relatively consistent with previous evaluations (Table 2).

Distributions of Stewart's wilt ratings differed for accessions collected from the United States and those collected from other countries (Table 1). Ratings for the 938 U.S. accessions ranged from 1 to 8.5 with a mean of 3.7 , a median of 3.5 , and a standard deviation of 1.15 . Ratings for the 1,053 non-U.S. accessions ranged from 1.5 to 9 with a mean and median of 4.3 and a standard deviation of 0.97 . Thirty-three of 38 accessions rated below 2 and 176 of 230 accessions rated from 2.0 to 2.99 were from the United States (Table 1).

Mean Stewart's wilt ratings differed among accessions from various regions of the world (Table 1). The mean Stewart's wilt rating of accessions from the Mid-
Atlantic/Ohio River Valley of the United States was 3.1 which was lower than means of accessions from all other regions. The mean rating of accessions from the southern United States was 3.7, which also was different from mean ratings of accessions from all other regions. The mean rating of accessions from the northeastern United States was 4.6, which was higher than means of accessions from all other regions except those from North and Central America (excluding the United States) and Asia/South Pacific/Middle East.

Distributions of reactions to Stewart's wilt were relatively similar for non-U.S. and U.S. accessions when accessions from the Mid-Atlantic/Ohio River Valley area and southern United States were excluded from the comparison. The mean and median for Stewart's wilt rating were 4 for U.S. accessions when accessions collected from the Mid-Atlantic/Ohio River Valley area and southern United States were excluded. 
The number of accessions rated below 2 and between 2 and 2.99 differed among regions (Table 1). Most of the accessions with low Stewart's wilt ratings were from the Mid-Atlantic/Ohio River Valley or the U.S. Corn Belt. Forty-one percent of the accessions from the Mid-Atlantic/Ohio River Valley were rated below 3, and 9\% (23 accessions) were rated below 2. Approximately $16 \%$ of the accessions from all other regions of the United States except for the Northeast were rated below 3, but only 10 of 633 accessions were rated below 2 . For all other regions of the world, 4 to $9 \%$ of the accessions were rated below 3 and only five accessions were rated below 2 .

The number of accessions rated 5 or above also differed among regions (Table 1). Over $30 \%$ of the accessions from the northeastern United States and from Asia/South Pacific/Middle East were rated 5 or above. For all other areas of the world except the southern United States and the
Mid-Atlantic/Ohio River Valley, 17 to $24 \%$ of the accessions were rated 5 or above. Only $7 \%$ of the accessions from the southern United States and $4 \%$ of the accessions from the Mid-Atlantic/Ohio River Valley were rated 5 or above.

Among the accessions from the United States, those from Virginia and Kentucky had the lowest Stewart's wilt ratings, and those from New Mexico, Wyoming, Massachusetts, Rhode Island, and Maine had the highest Stewart's wilt ratings (Table 3). Although the mean Stewart's wilt rating for accessions from the South was less than that for all other regions of the United States except for the Mid-Atlantic/Ohio River Valley area, only one accession from South Carolina was rated below 2, and the percentage of accessions from the South rated below 3 did not differ significantly from that of accessions from all other regions of the United States except the Northeast.
Some accessions from every continent were rated below 3 (Tables 1 and 4). Means, ranges, and number of accessions rated below 3 or above 4.99 tended to vary among countries, possibly due to considerably different sample sizes (Table 4). The range of accession means was about 4 or more for countries with at least 20 accessions, except for Ethiopia, Brazil, and China, for which the range of means was 3 or less. Stewart's wilt reactions differed among accessions from different countries on the same continent or in the same region of the world (Table 4). For example, Stewart's wilt ratings for accessions from Brazil and Uruguay were generally lower than those for accessions from other South American countries. Conversely, half or more of the accessions from Algeria, Peru, Romania, Canada, and Israel were rated 5 or above, and a large percentage of the accessions from Chili, Argentina, Hungary, Yugoslavia, the former Soviet

Table 4. Mean Stewart's wilt ratings in 1997, standard deviations, ranges, and number of maize accessions from various countries of the world rated below 2 , from 2 to 2.99 , from 3 to 4.99 , and above 4.99

\begin{tabular}{|c|c|c|c|c|c|c|c|c|}
\hline \multirow[b]{2}{*}{ Region $^{x}$} & \multirow[b]{2}{*}{$n$} & \multicolumn{3}{|c|}{ Stewart's wilt ratings ${ }^{\mathbf{y}}$} & \multicolumn{4}{|c|}{ No. of accessions } \\
\hline & & Mean & SD & Range & $<2$ & $2-2.99$ & 3-4.99 & $\geq 5$ \\
\hline United States & 938 & 3.7 & 1.15 & $1-8.5$ & 33 & 178 & 581 & 146 \\
\hline \multicolumn{9}{|l|}{ Africa } \\
\hline Kenya/Egypt & 3 & 3.3 & 0.66 & $2.8-4$ & 0 & 1 & 2 & 0 \\
\hline Ethiopia & 29 & 3.5 & 0.77 & $2-5$ & 0 & 4 & 24 & 1 \\
\hline South Africa & 25 & 4.1 & 1.14 & $2.3-7.3$ & 0 & 2 & 19 & 4 \\
\hline Morocco & 9 & 4.9 & 0.71 & $3.8-6$ & 0 & 0 & 6 & 3 \\
\hline Algeria & 16 & 5.1 & 0.68 & $3-5.8$ & 0 & 0 & 4 & 12 \\
\hline \multicolumn{9}{|l|}{ South America } \\
\hline Brazil & 22 & 3.0 & 0.54 & $2.3-4.5$ & 0 & 9 & 13 & 0 \\
\hline Uruguay & 30 & 3.5 & 0.88 & $2.3-6.5$ & 0 & 8 & 21 & 1 \\
\hline Venezuela/Bolivia/Paraguay & 9 & 4.0 & 1.02 & $2.8-6$ & 0 & 1 & 7 & 1 \\
\hline Chili & 44 & 4.3 & 0.71 & $3.3-5.8$ & 0 & 0 & 33 & 11 \\
\hline Columbia & 17 & 4.3 & 0.50 & $3.5-5$ & 0 & 0 & 14 & 3 \\
\hline Argentina & 55 & 4.5 & 1.16 & $2.8-8.3$ & 0 & 1 & 39 & 15 \\
\hline Peru & 30 & 4.8 & 0.78 & $3.8-6.5$ & 0 & 0 & 15 & 15 \\
\hline \multicolumn{9}{|l|}{ Europe } \\
\hline Spain & 18 & 4.1 & 1.01 & $1.5-5.3$ & 2 & 0 & 12 & 4 \\
\hline Poland & 37 & 4.1 & 1.03 & $2.5-6.5$ & 0 & 3 & 28 & 6 \\
\hline Hungary & 43 & 4.1 & 0.97 & $1.8-6.3$ & 1 & 3 & 30 & 9 \\
\hline Yugoslavia & 297 & 4.2 & 0.77 & $2.3-8$ & 0 & 6 & 240 & 51 \\
\hline France & 15 & 4.3 & 0.82 & $2.5-5.5$ & 0 & 1 & 12 & 2 \\
\hline Portugal & 6 & 4.3 & 0.44 & $3.5-4.8$ & 0 & 0 & 6 & 0 \\
\hline Romania & 19 & 4.4 & 1.19 & $2.3-6.3$ & 0 & 2 & 9 & 8 \\
\hline Ukraine & 7 & 4.4 & 0.80 & $2.8-5$ & 0 & 1 & 3 & 3 \\
\hline Former Soviet Union & 53 & 4.4 & 1.04 & $1.8-6.5$ & 2 & 1 & 30 & 20 \\
\hline Germany/Netherlands & 8 & 4.5 & 0.87 & $3.8-5.8$ & 0 & 0 & 7 & 1 \\
\hline Italy & 74 & 4.7 & 0.78 & $3-6.8$ & 0 & 0 & 42 & 32 \\
\hline Bulgaria & 5 & 5.0 & 0.80 & $4-6$ & 0 & 0 & 3 & 2 \\
\hline \multicolumn{9}{|l|}{ North and Central America ${ }^{\mathrm{z}}$} \\
\hline Virgin Is./Cuba/Barbados/Puerto Rico & 7 & 3.7 & 0.78 & $3.3-4.3$ & 0 & 0 & 7 & 0 \\
\hline Mexico/Guatemala & 22 & 3.8 & 0.96 & $2.8-7.5$ & 0 & 2 & 19 & 1 \\
\hline Canada & 15 & 5.5 & 2.09 & $2-9$ & 0 & 1 & 6 & 8 \\
\hline \multicolumn{9}{|l|}{ Asia/South Pacific/Middle East } \\
\hline Taiwan & 1 & 2.0 & $\ldots$ & $\ldots$ & 0 & 1 & 0 & 0 \\
\hline China & 30 & 3.9 & 0.82 & $2.3-5.3$ & 0 & 3 & 24 & 3 \\
\hline Australia/New Zealand & 10 & 4.1 & 1.30 & $3-7$ & 0 & 0 & 8 & 2 \\
\hline Bhutan/Nepal/India/Indones./Afghan. & 11 & 4.1 & 1.05 & $3-5.5$ & 0 & 0 & 8 & 3 \\
\hline Turkey & 50 & 4.5 & 0.69 & $2.8-6$ & 0 & 1 & 31 & 18 \\
\hline Jordan/Syria/Iran & 4 & 4.5 & 0.92 & $3.5-5.5$ & 0 & 0 & 3 & 1 \\
\hline Japan & 22 & 4.6 & 1.17 & $2.3-7$ & 0 & 2 & 12 & 8 \\
\hline Israel & 10 & 5.4 & 1.48 & $3-7.8$ & 0 & 0 & 5 & 5 \\
\hline
\end{tabular}

${ }^{x}$ Region from which accessions were collected.

${ }^{y}$ Stewart's wilt ratings from 1 to 9 , where $1=$ little or no spread, $2=$ spread of about $3 \mathrm{~cm}, 3=$ spread toward tip end of leaf only, $5=$ limited systemic infection, $9=$ dead plants.

${ }^{\mathrm{z}}$ Excluding the United States. 
Union, Italy, Turkey, and Japan were rated 5 or above.

Trials in 1998 and 1999. Stewart's wilt reactions of accessions evaluated in 1998 and 1999 were relatively similar to those in 1997. Early and late ratings within 1998 and 1999 were correlated (coefficients ranging from 0.85 to 0.98 , Table 5), so means of the two ratings were compared among years. The correlation coefficient for ratings of 292 accessions and sweet corn hybrid checks in 1997 and 1998 was 0.87 (Fig. 1). Correlation coefficients between ratings in 1997 and 1998 ranged from 0.67 to 0.90 for the three different trials in 1998 (Table 5). Correlation coefficients were 0.92 between ratings in 1999 and 1997, and 0.89 between ratings in 1999 and 1998. Ratings in the 1998 trial ranged from 1 to 2.8 for the 80 accessions rated 2 or below in 1997, while ratings for 15 sweet corn hybrid checks ranged from 1.5 to 5.8 in this trial. Accessions rated 2.25 or 2.5 in 1997 were rated from 1.4 to 5.5 in the 1998 trial, and sweet corn checks ranged from 1.3 to 6.3 .

Stewart's wilt ratings in 1997 and 1998 were less than 2 for 20 accessions (Table 6); however, ratings for these accessions ranged from 1.7 to 3.1 in 1999 when Stewart's wilt was severe. Seven of the 20 accessions were from Virginia, seven were from the Ohio River Valley or central Corn Belt, four were from the northern or western Corn Belt, and two were from Spain (Table 6). Ratings among these accessions were not significantly different in 1997 , and only a few accessions were different in 1998 and 1999. Stewart's wilt ratings of $F_{1}$ hybrids of accessions crossed with susceptible sweet corn inbreds were slightly higher than ratings of the resistant accession, but $F_{1}$ hybrids were rated considerably lower than the susceptible inbred in the cross (Table 6). Among the $F_{1}$ hybrids, mean Stewart's wilt ratings were lowest for crosses with KyWS6, although ratings were not significantly different between most of the $F_{1}$ hybrids, and KyWS6 was not the most resistant accession.

\section{DISCUSSION}

In this study, maize germ plasm adapted to temperate climates but collected from various regions of the world had a similar distribution of reactions to E. stewartii, except for germ plasm from the Mid-Atlantic/Ohio River Valley region of the United States, the southern United States, and the northeastern United States. Accessions from the Mid-Atlantic/Ohio River Valley and the southern United States were more resistant to Stewart's wilt than other germ plasm evaluated. Accessions from the northeastern United States were more susceptible.

Reactions of accessions from the MidAtlantic/Ohio River Valley and the southern United States reflect a response to persistent selection pressure. Stewart's wilt was endemic in the Mid-Atlantic/Ohio River Valley region for the past century $(13,14)$ and probably for hundreds of years prior to the identification of the disease in 1897 (16). In this region, plants with resistance have been selected, and those with susceptibility have been eliminated either by man or by nature. Stewart's wilt epidemics have been sporadic $500 \mathrm{~km}$ north or south of this region, and the disease has been reported only occasionally from other areas of the world (13). Thus, it is not surprising that $63 \%$ of the accessions rated below 2 and $46 \%$ of the accessions rated from 2 to 2.99 were from the Mid-Atlantic/Ohio River Valley and the southern United States.

Sources of moderately resistant reactions (i.e., ratings from 2 to 2.99) occurred in accessions from nearly all regions evaluated, but high levels of resistance occurred only in accessions from a restricted area of the United States and a few European countries. Fourteen of the 20 accessions with the most resistant reactions to Stewart's wilt were from areas where Stewart's wilt is endemic or frequently epidemic. Resistant accessions from Europe may be U.S. germ plasm that was introduced to Europe and subsequently collected from there.
Many of the resistant accessions in our evaluation may possess a resistance gene identified from Va35 (9), but some may possess other genes for resistance. Pedigrees should be examined and progeny from test crosses evaluated as an initial procedure to determine if these sources of resistance differ. The highly resistant accessions should be evaluated further, and inheritance of resistance from these sources should be determined. In the event that E. stewartii becomes established in areas where it is not currently a problem, these accessions and other sources of high levels of resistance $(2,5,6,8-10,15,18)$ can be used to develop resistant cultivars.

The frequency of highly susceptible accessions (i.e., those rated 6 and above) were similar for non-U.S. and U.S. accessions; however, accessions from the northeastern United States and Asia/South Pacific/Middle East were systemically infected more frequently than other accessions. More than half of the accessions from the northeastern United States were early-maturing sweet corn lines and openpollinated cultivars which are known to be susceptible to Stewart's wilt $(5,12)$. Sweet

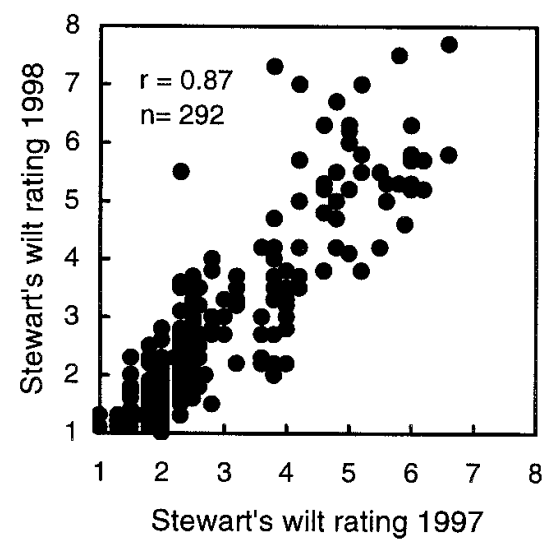

Fig. 1. Stewart's wilt ratings from 1 (no appreciable spread of symptoms) to 9 (dead plants) for 292 maize accessions and sweet corn hybrid checks inoculated with Erwinia stewartii in 1997 and 1998.

Table 5. Summary statistics for Stewart's wilt ratings of maize accessions in 1998 and 1999

\begin{tabular}{|c|c|c|c|c|c|c|c|}
\hline \multirow[b]{2}{*}{ Year and trial } & \multirow[b]{2}{*}{$n$} & \multirow[b]{2}{*}{ Mean } & \multirow[b]{2}{*}{ SD } & \multirow[b]{2}{*}{ Range } & \multirow[b]{2}{*}{ BLSD } & \multicolumn{2}{|c|}{ Correlation coefficients } \\
\hline & & & & & & Both ratings ${ }^{t}$ & 1997 ratings $^{u}$ \\
\hline \multicolumn{8}{|l|}{1998} \\
\hline Accessions $\leq 2^{\mathrm{v}}$ & 95 & 1.8 & 1.04 & $1-5.8$ & 0.61 & 0.98 & 0.90 \\
\hline Accessions $>2$ and $\leq 2.5^{\mathrm{w}}$ & 125 & 2.4 & 0.77 & $1.3-6.3$ & 1.03 & 0.93 & 0.67 \\
\hline Random accessions $\mathrm{s}^{\mathrm{x}}$ & 96 & 4.1 & 1.53 & $1.5-7.7$ & $\ldots$ & 0.94 & 0.77 \\
\hline \multicolumn{8}{|l|}{1999} \\
\hline Accessions and $\mathrm{F}_{1}$ hybrids $^{\mathrm{y}}$ & 51 & 3.2 & 0.97 & $1.7-7.0$ & 0.58 & 0.85 & $0.92^{\mathrm{z}}$ \\
\hline $\begin{array}{l}\text { Correlation of ratings at pre } \\
\text { u Correlation with ratings fror } \\
\text { v Accessions rated } 2 \text { or below } \\
{ }^{\mathrm{v}} \text { Accessions rated from } 2 \text { to } \\
{ }^{\mathrm{x}} \text { Accessions selected at rand } \\
\mathrm{y} \text { Twenty accessions with lov } \\
\text { checks. } \\
\text { z Correlation based on } 20 \text { acc }\end{array}$ & $\begin{array}{l}- \text { tassel } \\
\text { aluati } \\
\text { and } 15 \\
7 \text { and } \\
\text {,986 e } \\
\text { s in } 1\end{array}$ & $\begin{array}{l}\text { rn hybri } \\
\text { orn hybi } \\
\text { in } 1997 \\
1998, F \\
\text { hybrid }\end{array}$ & $\begin{array}{l}\text { s. } \\
\text { veet co } \\
\text { of the }\end{array}$ & $\begin{array}{l}\text { d checks. } \\
\text { ssions witl }\end{array}$ & ible su & n inbreds, and & $\begin{array}{l}\text { weet corn hybric } \\
\text { D.89. }\end{array}$ \\
\hline
\end{tabular}


Table 6. Stewart's wilt ratings for maize accessions, $F_{1}$ crosses, and sweet corn hybrids and inbreds evaluated in 1997, 1998, and 1999

\begin{tabular}{|c|c|c|c|c|c|c|c|}
\hline \multirow{2}{*}{$\begin{array}{l}\text { Accession, hybrid, } \\
\text { or inbred }\end{array}$} & \multirow[b]{2}{*}{ Origin } & \multicolumn{4}{|c|}{ Stewart's wilt rating } & \multicolumn{2}{|c|}{$F_{1}$ hybrid rating $^{x}$} \\
\hline & & Mean & 1997 & 1998 & 1999 & CrseW30 & Crse16 \\
\hline Va 37 & VA & $1.4^{\mathrm{y}}$ & 1.0 & 1.1 & 2.1 & 3.0 & $\ldots$ \\
\hline $\mathrm{Pa} 891$ & $\mathrm{PA}$ & 1.5 & 1.3 & 1.2 & 2.1 & $\ldots$ & $\ldots$ \\
\hline Va 59 & VA & 1.5 & 1.3 & 1.2 & 2.1 & 3.2 & 3.3 \\
\hline Inbred 1032 & Spain & 1.6 & 1.5 & 1.3 & 1.9 & $\ldots$ & $\ldots$ \\
\hline $\mathrm{SD} 40$ & $\mathrm{SD}$ & 1.6 & 1.3 & 1.3 & 2.1 & 2.6 & 3.3 \\
\hline Va 17 & VA & 1.6 & 1.3 & 1.1 & 2.3 & 3.2 & 3.2 \\
\hline Mo 17 & MO & 1.6 & 1.8 & 1.3 & 1.7 & 3.0 & 2.8 \\
\hline Inbred 1037 & Spain & 1.6 & 1.8 & 1.3 & 1.7 & 2.8 & 3.3 \\
\hline W 182B & WS & 1.7 & 1.5 & 1.3 & 2.3 & $\ldots$ & $\ldots$ \\
\hline B 85 & IA & 1.7 & 1.3 & 1.3 & 2.6 & 3.3 & 3.0 \\
\hline $89 S 4154$ & NB & 1.8 & 1.5 & 1.3 & 2.5 & 3.2 & 3.1 \\
\hline Va 22 & VA & 1.8 & 1.8 & 1.3 & 2.2 & 3.1 & 3.3 \\
\hline Va 38 & VA & 1.8 & 1.8 & 1.3 & 2.2 & 3.1 & $\ldots$ \\
\hline Va 24 & VA & 1.8 & 1.8 & 1.5 & 2.2 & 3.3 & 3.3 \\
\hline KyWS6 & KY & 2.0 & 1.8 & 1.2 & 3.1 & 2.6 & 2.8 \\
\hline KyWS5 & KY & 2.0 & 1.8 & 1.6 & 2.7 & $\ldots$ & 3.2 \\
\hline M14 & IL & 2.1 & 1.8 & 1.7 & 2.7 & 3.2 & 3.4 \\
\hline W 64A & WS & 2.1 & 1.8 & 1.8 & 2.7 & 3.2 & 3.7 \\
\hline Bonus & & 2.1 & 1.6 & 1.3 & 3.4 & $\ldots$ & $\ldots$ \\
\hline Va $21 \mathrm{~A}$ & VA & 2.1 & 1.8 & 1.5 & 3.1 & 3.2 & 3.4 \\
\hline B 84 & IA & 2.2 & 1.5 & 1.9 & 3.0 & 3.6 & 3.7 \\
\hline Miracle & & 2.2 & 1.9 & 2.1 & 2.7 & $\ldots$ & $\ldots$ \\
\hline Eliminator & & 2.5 & 2.6 & 1.8 & 3.0 & $\ldots$ & $\ldots$ \\
\hline Ambrosia & & 2.7 & 2.7 & 2.0 & 3.4 & $\ldots$ & $\ldots$ \\
\hline Reveille & & 4.6 & 5.0 & 4.1 & 4.8 & $\ldots$ & $\ldots$ \\
\hline Jubilee & & 5.4 & 5.9 & 4.6 & 5.7 & $\ldots$ & $\ldots$ \\
\hline Crse W30 & & $\ldots$ & $\ldots$ & $\ldots$ & 5.7 & $\ldots$ & $\ldots$ \\
\hline Crse16 & & $\ldots$ & $\ldots$ & $\ldots$ & 5.4 & $\ldots$ & $\ldots$ \\
\hline BLSD $k=100$ & & & 0.56 & 0.61 & $0.58^{z}$ & & \\
\hline
\end{tabular}

${ }^{x} F_{1}$ hybrids of accessions crossed with early-maturing, Stewart's wilt susceptible sweet corn inbreds CrseW30 and Crse16. Rated in 1999.

y Stewart's wilt rating from 1 to 9 , where $1=$ little or no spread, $2=$ spread of about $3 \mathrm{~cm}, 3=$ spread toward tip end of leaf only, $5=$ limited systemic infection, $9=$ dead plants.

${ }^{\mathrm{z}}$ BLSD multiple comparison value for all lines evaluated in 1999 including accessions, $\mathrm{F}_{1}$ hybrids, and CrseW30 and Crse16.

corn germ plasm was not a large proportion of the accessions sampled from any other region.

The accessions evaluated in this trial probably do not adequately reflect the germ plasm grown presently in many temperate climates of the world. Cultivars grown in temperate climates may be more resistant to Stewart's wilt than the accessions evaluated in this study if U.S. Corn Belt germ plasm has been used for genetic improvement. Many of the U.S. accessions which had highly resistant (1 to 1.99 ) or moderately resistant (2 to 2.99 ) reactions to Stewart's wilt in our trial are prominent in pedigrees of widely grown, U.S. Corn Belt germ plasm (e.g., B37, B75, B84, B85, B73 $\times$ Mo17, BS13, BSAA, Mo17, PA Composite II, PA Composite III, and others). Conversely, if early-maturing germ plasm from the northeastern United States has been used to develop or improve lines throughout the world, especially sweet corn lines, those lines may be more susceptible than the average accession from this collection.

\section{ACKNOWLEDGMENTS}

We thank Mark Millard, maize curator at the NCRPIS, Ames, IA, for seed and for recommendations of which accessions to evaluate; and Chet Kurowski, Harris Moran Seed Company, San Juan
Bautista, CA, for assistance with Stewart's wilt ratings.

\section{LITERATURE CITED}

1. Blanco, M. H., Johnson, M. G., Colbert, T. R., and Zuber, M. S. 1977. An inoculation technique for Stewart's wilt disease of corn. Plant Dis. Rep. 61:413-416.

2. Blanco, M. H., Zuber, M. S., Wallin, J. R., Loonan, D. V., and Krause, G. F. 1979. Host resistance to Stewart's disease in maize. Phytopathology 69:849-853.

3. Block, C. C., Hill, J. H., and McGee, D. C. 1998. Seed transmission of Pantoea stewartii in field and sweet corn. Plant Dis. 82:775780.

4. Chang, C. M., Hooker, A. L., and Lim, S. M. 1977. An inoculation technique for determining Stewart's bacterial blight reaction in corn. Plant Dis. Rep. 61:1077-1079.

5. Ivanoff, S. S. 1936. Resistance to bacterial wilt of open-pollinated varieties of sweet, dent, and flint corn. J. Agric. Res. 53:917926.

6. Ivanoff, S. S., and Riker, A. J. 1936. Resistance to bacterial wilt of inbred strains and crosses of sweet corn. J. Agric. Res. 53:927954.

7. Leppik, E. E. 1970. Gene centers of plants as sources of disease resistance. Annu. Rev. Phytopathol. 8:323-344.

8. Meyer, A. C., Pataky, J. K., and Juvik, J. A. 1991. Partial resistance to northern leaf blight and Stewart's wilt in sweet corn germ plasm. Plant Dis. 75:1094-1097.

9. Ming, R., Brewbaker, J. L., Moon, H. G., Musket, T. A., Holley, R. N., Pataky, J. K., and McMullen, M. D. 1999. Identification of RFLP markers linked to a major gene, swl, conferring resistance to Stewart's wilt in maize. Maydica 44:319-323.

10. Parker, G. E., and Hooker, A. L. 1993. Inheritance of resistance to Erwinia stewartii in four inbred lines of dent corn: Qualitative and quantitative analyses. Maydica 38:221-229.

11. Pataky, J. K., and du Toit, L. J. 1997. Sweet corn hybrid disease nursery - 1997. Pages 99111 in: Midwestern vegetable variety trial report for 1997. Purdue Univ. Agric. Exp. Stn. Bull. 758.

12. Pataky, J. K., du Toit, L. J., Revilla, P., and Tracy, W. F. 1998. Reactions of open-pollinated sweet corn cultivars to Stewart's wilt, common rust, northern leaf blight, and southern leaf blight. Plant Dis. 82:939-944.

13. Pepper, E. H. 1967. Stewart's bacterial wilt of corn. American Phytopathological Society Monogr. 4.

14. Roberts, A. L. 1955. Bacterial wilt and Stewart's leaf blight of corn. U.S. Dep. Agric. Farmer's Bull. 2092.

15. Smith, D. R. 1971. Inheritance of reaction to Stewart's disease (bacterial wilt) in dent corn MS thesis. University of Illinois, Urbana.

16. Stewart, F. C. 1897. A bacterial disease of sweet corn. N.Y. Agric. Exp. Stn. Bull. 130.

17. Suparyono and Pataky, J. K. 1989. Influence of host resistance and growth stage at the time of inoculation on Stewart's wilt and Goss's wilt development and sweet corn hybrid yield. Plant Dis. 73:339-345.

18. Wellhausen, E. J. 1937. Genetics of resistance to bacterial wilt in maize. Ia. Agric. Exp. Stn. Bull. 224:69-114. 